\title{
Status and distribution of Paraguayan macaws (Aves: Psittacidae) with a new country record
}

\author{
Oscar Rodríguez ; ${ }^{1}$ Leandro Castillo ${ }^{2}$; Paul Smith ${ }^{3}$ \& Hugo del Castillo ${ }^{4}$ \\ 1 Universidad Americana. Asunción, Paraguay. E-mail: oscar.rodriguez.scelza@gmail.com \\ 2 Jardín de los Picaflores. Puerto Iguazú, Argentina. E-mail: leandrocastillo_00@hotmail.com \\ 3 FAUNA Paraguay. Encarnación, Paraguay; Fundación Para La Tierra. Ñeembucú, Paraguay. \\ ORCID: http://orcid.org/0000-0002-8758-4816. E-mail: faunaparaguay@gmail.com \\ ${ }^{4}$ Asociación Guyra Paraguay. Asunción, Paraguay. E-mail: hugofdelcastillo@gmail.com
}

\begin{abstract}
Eight species of macaw (Psittacidae: Anodorhynchus, Ara, Primolius) have previously been reported from Paraguay. We discuss all verifiable reports of the species from Paraguay and provide comment on their statuses. Ara chloropterus and Primolius auricollis are both widespread species known from multiple reports across a wide geographic area. We report minor range extensions within Paraguay for both species. Anodorhynchus hyacinthinus is documented as a breeding resident with a restricted distribution in the Upper Paraguay River basin. The first modern records of Ara ararauna and the first record of Diopsittaca nobilis for the country are documented with photographs. We are unable to find any confirmed records of Anodorhynchus glaucus from Paraguay and thus consider it of possible occurrence. Two species are rejected as erroneously cited, Ara militaris and Ara glaucogularis. Consequently six species in four genera are now confirmed to occur in Paraguay.
\end{abstract}

Key-Words. Anodorhynchus; Ara; Diopsittaca; Primolius.

\section{INTRODUCTION}

Though not a monophyletic taxonomic group (Tavares et al., 2006), macaws are recognizable amongst the Psittacids because of their large size, long tails, colourful plumage and areas of bare skin on the head (Juniper \& Parr, 1998). These characteristics make macaws highly desirable for the pet trade, and on a global scale the populations of many species are in sharp decline (Ridgely, 1981; Inskipp et al., 1988).

A total of six species in three genera have been previously accepted as occurring in Paraguay (Guyra Paraguay, 2004): two "blue macaws" in the genus Anodorhynchus, two "typical macaws" in the genus Ara and two "Maracanás" in the genus Primolius. Two further species in the genus Ara have featured in the Paraguayan literature, but these are generally accepted to be in error. In this paper we review the status and distribution of Paraguayan macaws, and document for the first time the presence of a fourth genus, Diopsittaca, in the north east of the country.

\section{MATERIAL AND METHODS}

We compiled records of macaws in Paraguay from the published literature, museum speci- mens, the authors' own field observations and through consultations with ornithologists and birdwatchers. Unpublished noteworthy distributional reports lacking identification details were omitted. A gazetteer of localities mentioned in the text is provided in Appendix 1.

Acronyms of museum collections referred to in the text are listed: AMNH = American Museum of Natural History, New York, USA; ANSP = Academy of Natural Sciences, Philadelphia, USA; CUMV = Cornell University Museum of Vertebrates, Ithaca, USA; FMNH = Field Museum of Natural History, Chicago, USA; KU = University of Kansas Biodiversity Institute, USA; MACN = Museo Argentino de Ciencias Naturales, Buenos Aires, Argentina; MNHNP = Museo Nacional de Historia Natural del Paraguay, San Lorenzo, Paraguay; MHNG = Natural History Museum of Geneva, Geneva, Switzerland; MNRdJ = Museu Nacional, Rio de Janeiro, Brazil; NHM = The Natural History Museum, London, UK; RMNH = Rijksmuseum van Natuurlijke Historie, Leiden, Netherlands; UMMZ = University of Michigan Museum of Zoology, Ann Arbor, USA; USNM = National Museum of Natural History, Smithsonian Institute, Washington D.C., USA; ZSM = Zoologische Staatssammlung München, Munich, Germany. 


\section{RESULTS}

\section{Hyacinth Macaw Anodorhynchus hyacinthinus} Figs. 1, 4

Ridgely (1981) stated that local hunters in the Rio Apa area were familiar with the species and that it "crosses over at times from adjacent Mato Grosso". Munn et al. (1987), apparently speculatively, estimated that the population in Paraguay consisted of just a single pair, and López (1989) hinted at new records of the species in Concepción department. However, the first published locality was not until Hayes et al. (1990) who reported the species from Puerto María, Alto Paraguay department on 11 August 1988.

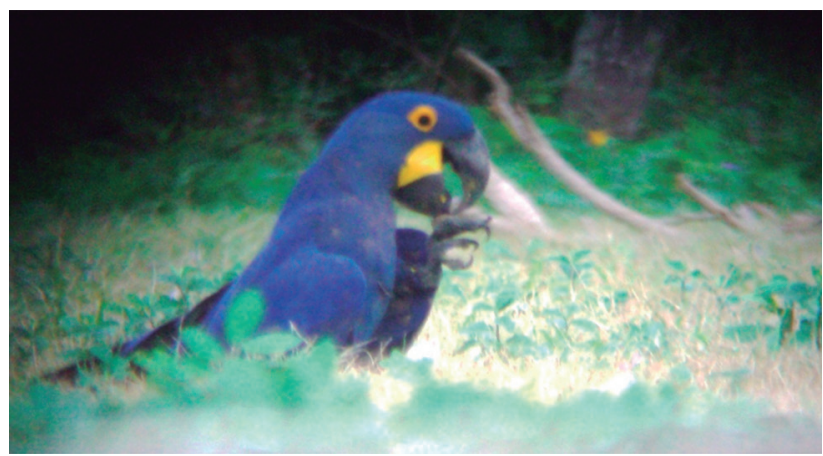

Figure 1. Hyacinth Macaw Anodorhynchus hyacinthinus Estancia Estrella, Concepción department, 04 December 2007. (Photo H. del Castillo).
López (1992) later summarised the results of her work on psittacids in Concepción department, observing the species at eight different estancias during fieldwork from September 1988 to October 1989: Estancia Buena Vista, Estancia Centurión, Estancia Loma Pora, Estancia Primavera, Estancia San Luís de la Sierra, Estancia Mirabeaud, Estancia Santa Sofía, Retiro Satí (the last three of these now within Paso Bravo National Park), as well as what is apparently the earliest observation of the species in Paraguay at "one km from Vallemí", Concepción department on 07 March 1984. The report of the species as rare in "Serranía San Luís National Park" (Robbins et al., 1999) refers to the area now known as Estancia Garay Kue. López (1992) doubted the veracity of a sight record south of Cerro Corá National Park, Amambay department, and there have been no further reports from that department.

Additional unpublished sight records from the Pantanal region west of the Paraguay River include Estancia Karenina (Antonio Spiridonof, 08 May 2003, sight record) and Cerro Chovoreca (Jorge Escobar \& Cristina Morales, feathers and local testimony), both in Alto Paraguay department. The first photographic documentation of the species was apparently by Hugo del Castillo at Estancia Estrella, Concepción department on 04 December 2007 (Fig. 2). The first photographic documentation of the species west of the Paraguay River that we are aware of is from near Base Aérea V Adrian Jara, Alto Paraguay department, by Ángel Brusquetti during July 2012.

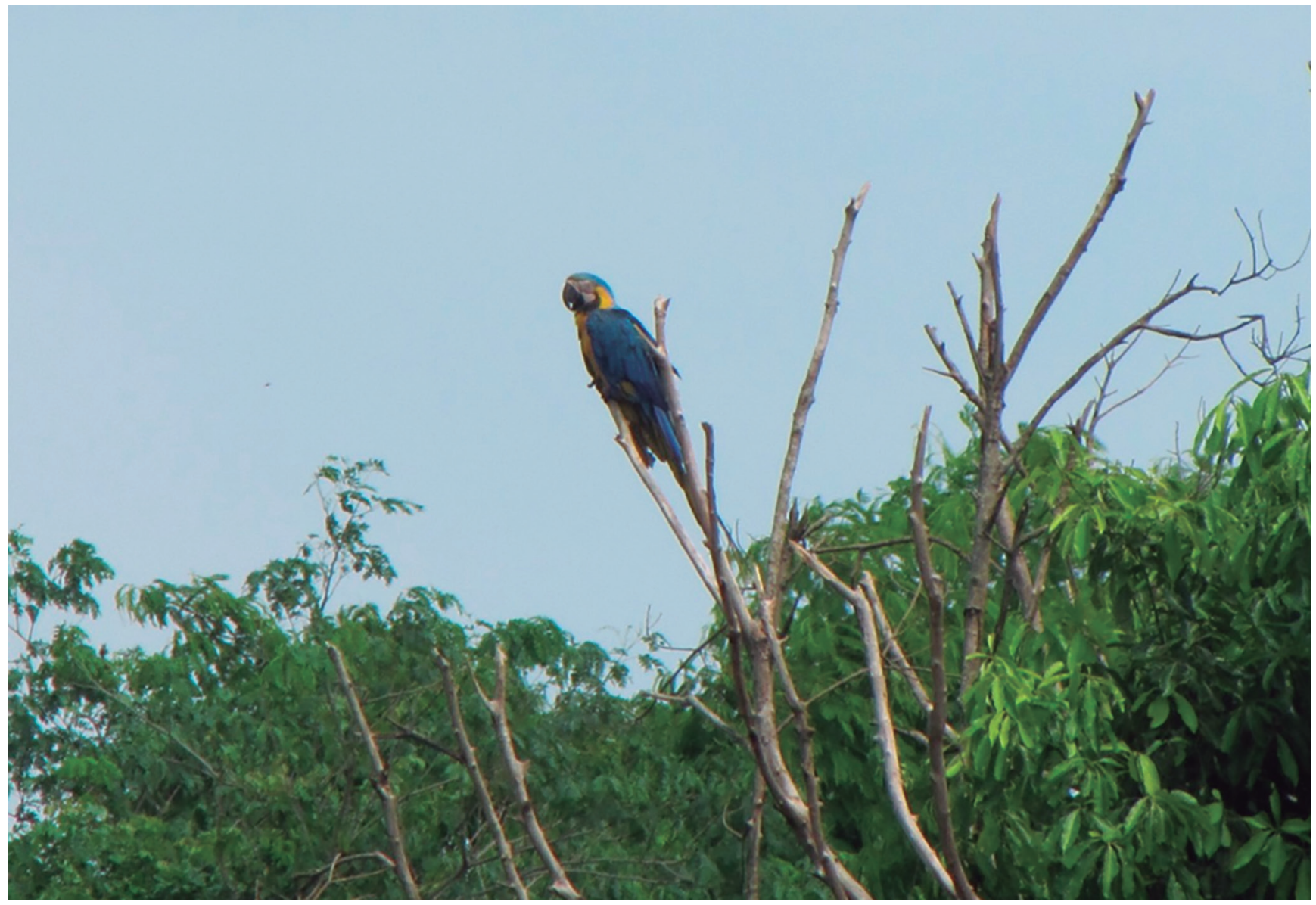

Figure 2. Blue-and-yellow Macaw Ara ararauna Aquidabán River on the road north to Bella Vista del Norte, 30 October 2010. (Photo 0. Rodríguez). 


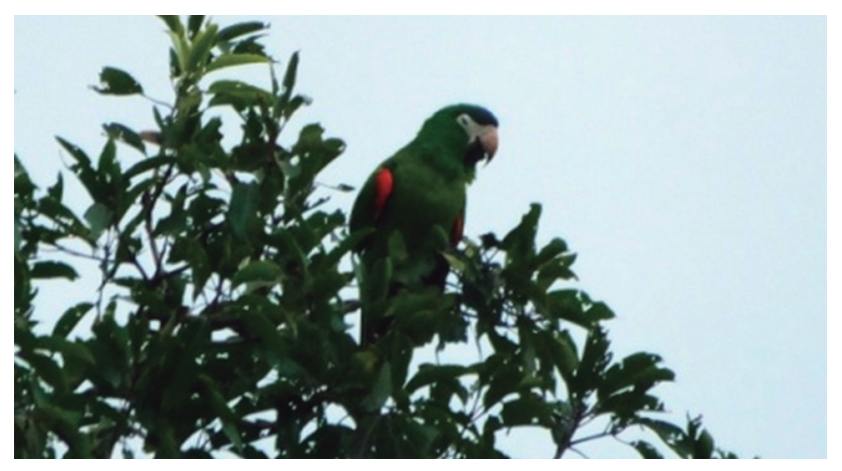

Figure 3. Red-shouldered Macaw Diopsittaca nobilis Estancia Laguna Ciervo, Amambay department, 01 May 2017. (Photo 0. Rodríguez).

The Paraguayan distribution is closely associated with the Cerrados del Chaco and Pantanal regions of northern and eastern Alto Paraguay, and the Cerrado of northwestern Concepción department. The species is a breeding resident with nesting documented photographically at Estancia Arrecife (S. Centrón pers. comm., 08 October 2010), Estancia Garay Kué on 27 April 2013 (OR) and a pair with young at Retiro San Luís de la Sierra on 13 May 2016 (OR photograph). Some individuals clearly commute between Paraguay and Brazil (Ridgely, 1981; Hayes et al.,1990). There exists the possibility that Sánchez Labrador's Guaa obi (Castex, 1968) refers "in part" to this species (see A. glaucus).

There is a single Paraguayan specimen of this species in the MNHNP that lacks locality data. The supposed specimen in the USNM (121049; 10 June 1887) collected by Riker at " 25 miles back from the Diamantina forest" cited by López (1992) is from Pará State, Brazil, not Paraguay.

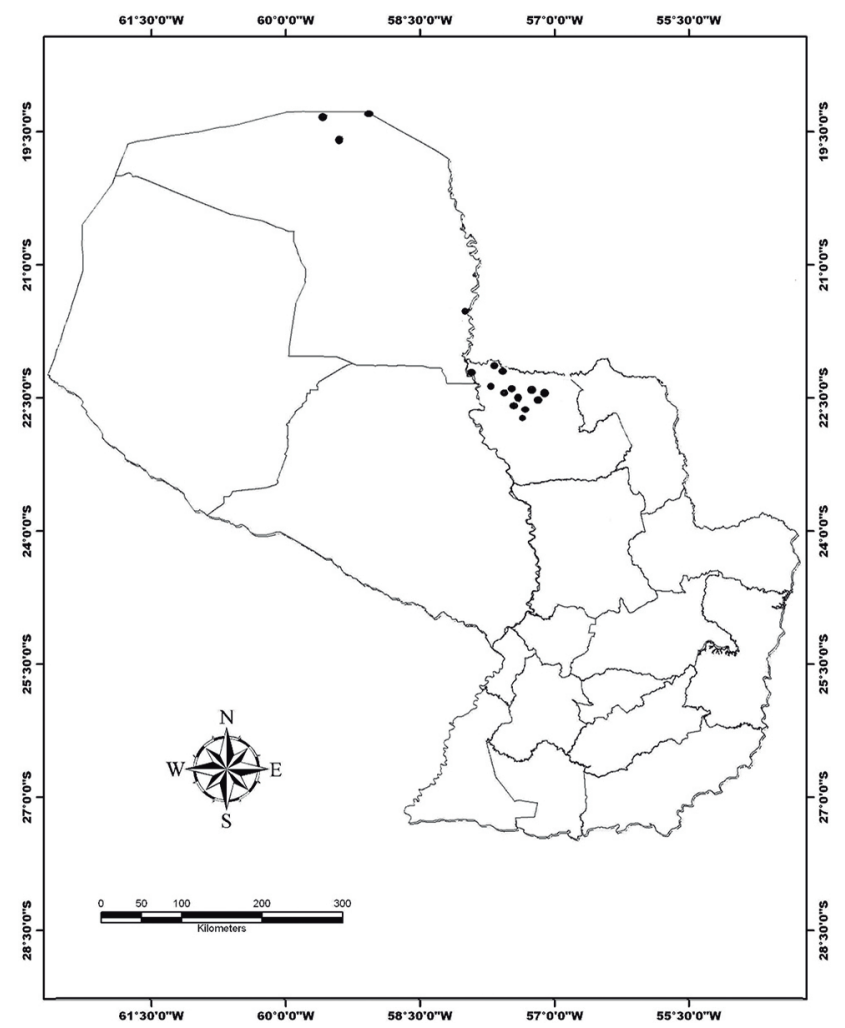

Figure 4. Distribution of Hyacinth Macaw Anodorhynchus hyacinthinus in Paraguay. Black dots: recent visual records.

\section{Blue-winged Macaw Primolius maracana}

Fig. 5

The first mention of the species in Paraguay is by Azara (1805) who described it as his "No. 274 Maracaná afeytado". Ridgely (1981) described the species as "inexplicably scarce" in Paraguay. Published departmental records are as follows: Alto Paraná (Podtiaguin, 1944; López, 1992; Brooks et al., 1993; Lowen et al., 1996), Amambay (Ridgely, 1981), Canindeyú (Ridgely, 1981; López, 1992; Mazar Barnett \& Madroño-Nieto, 2003), Caazapá (Madroño-Nieto et al., 1997; Velázquez et al., 2010), Concepción (Laubmann, 1939; Podtiaguin, 1944; López, 1992; Robbins et al., 1999), Guairá (Podtiaguin, 1944) and Presidente Hayes (Bertoni, 1930; Podtiaguin, 1944).

Additional recent unpublished records of note are: Estancia Laguna Ciervo, Amambay department (OR, 24, 25 June 2016, 26 April 2017, 11, 12 July 2017) and Estancia Itabó Rivas, Canindeyú department (OR, 12 June 2015). There also exist several unpublished records from San Pedro department including: Rancho Zastrow Saba (HdC, October 2017), Estancia Alegria (A. Bodrati, M. Velázquez: 2001), Estancia Don Luís (A. Bodrati, M. Velázquez: 28-30 July 2002), Estancia Guyra Campana (A. Bodrati, A. Esquivel, M. Velázquez: 02-06 June 2002) and Rancho 75 (A. Bodrati, M. Velázquez: 14-21 July 2002).

A single individual flying with a flock of 15 Monk Parakeets Myiopsitta monachus in Asunción, Central department (Arne Lesterhuis pers. comm., 10 May 2010), was assumed to be an escaped bird by the observer.

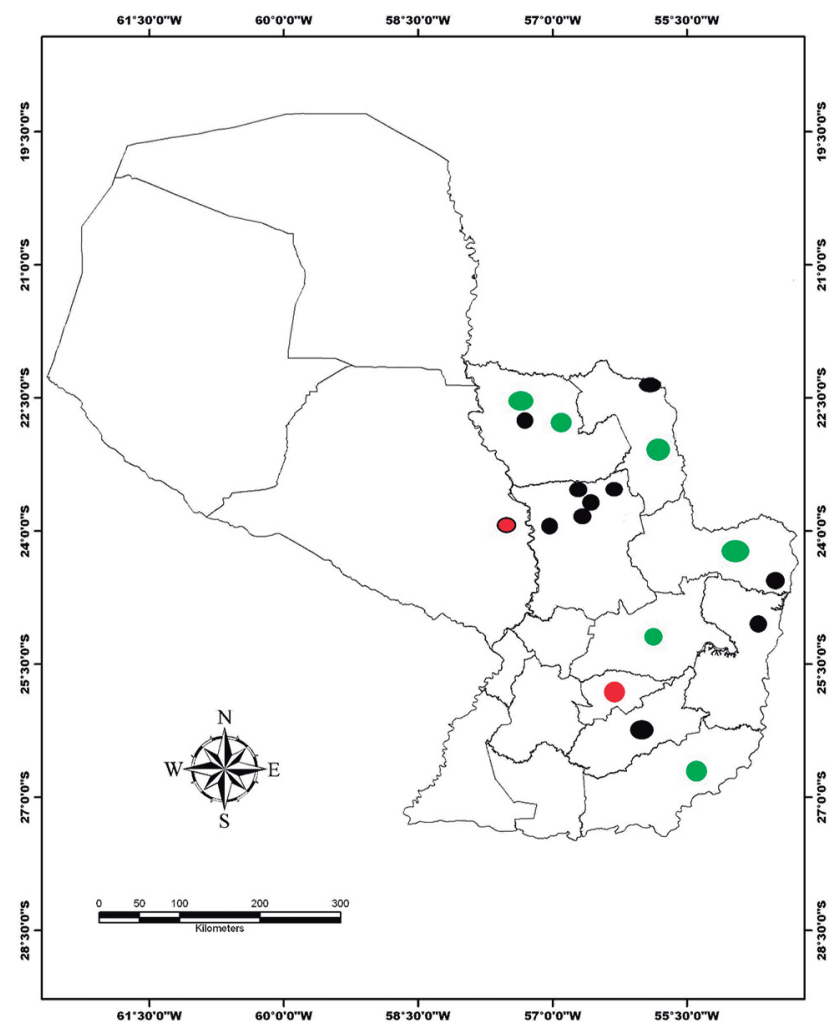

Figure 5. Distribution of Blue-winged Macaw Primolius maracana in Paraguay. Black dots: recent visual record, Red dots: historical bibliographic record, Green dots: specimen record. 
Table 1. Paraguayan specimens of Blue-winged Macaw Primolius maracana.

\begin{tabular}{|c|c|c|c|c|c|}
\hline Specimen & Locality & Department & Date & Collector & Source \\
\hline UMMZ 100709 & 40 km WSW Capitán Bado & Amambay & 13 October 1938 & Schulze & VertNet \\
\hline UMMZ 100994, 100995 & 40 km WSW Capitán Bado & Amambay & 19 0ctober 1938 & Schulze & VertNet \\
\hline UMMZ 100708, 105912 & 40 km WSW Capitán Bado & Amambay & 08 November 1938 & Schulze & VertNet \\
\hline UMMZ 100996 & 40 km WSW Capitán Bado & Amambay & 09 November 1938 & Schulze & VertNet \\
\hline AMNH 320317, 320318 & East of Caaguazú & Caaguazú & 23 November 1930 & Kaempfer & VertNet \\
\hline MNHNP 199 & $10 \mathrm{~km} \mathrm{~N}$ of Ygovy & Canindeyú & & López & López (1992) \\
\hline ZSM 32.381, 32.382 & San Luís de la Sierra & Concepción & 20 0ctober 1931 & Kiefer & Laubmann (1939) \\
\hline AMNH 319663 & Zanja Moroti & Concepción & 05 September 1930 & Kaempfer & VertNet \\
\hline UMMZ 200653, 200654 & $3.5 \mathrm{~km}$ E of San Rafael & Itapúa & 02 August 1978 & Storer & VertNet \\
\hline MACN & "Paraguay" & N/A & $\mathrm{N} / \mathrm{A}$ & Boccard & Orfila (1936) \\
\hline USNM 256883 & "Paraguay" (Questionable?) & N/A & $\mathrm{N} / \mathrm{A}$ & Page Expedition & N/A \\
\hline
\end{tabular}

The species is generally uncommon in Paraguay with most modern records coming from the northern and eastern Oriental region in the area of transition between the Cerrado and Atlantic Forest. There have been no recent reports from the Chaco region, but the presence of the species on the east bank of the Paraguay River in Concepción department makes marginal occurrence in Presidente Hayes and Alto Paraguay departments possible.

Details of specimens that we are aware of are provided in Table 1.

\section{Yellow-collared Macaw Primolius auricollis Fig. 6}

The first report of this species in Paraguay was of two females (specimens 242, 245) collected at Colonia Risso,

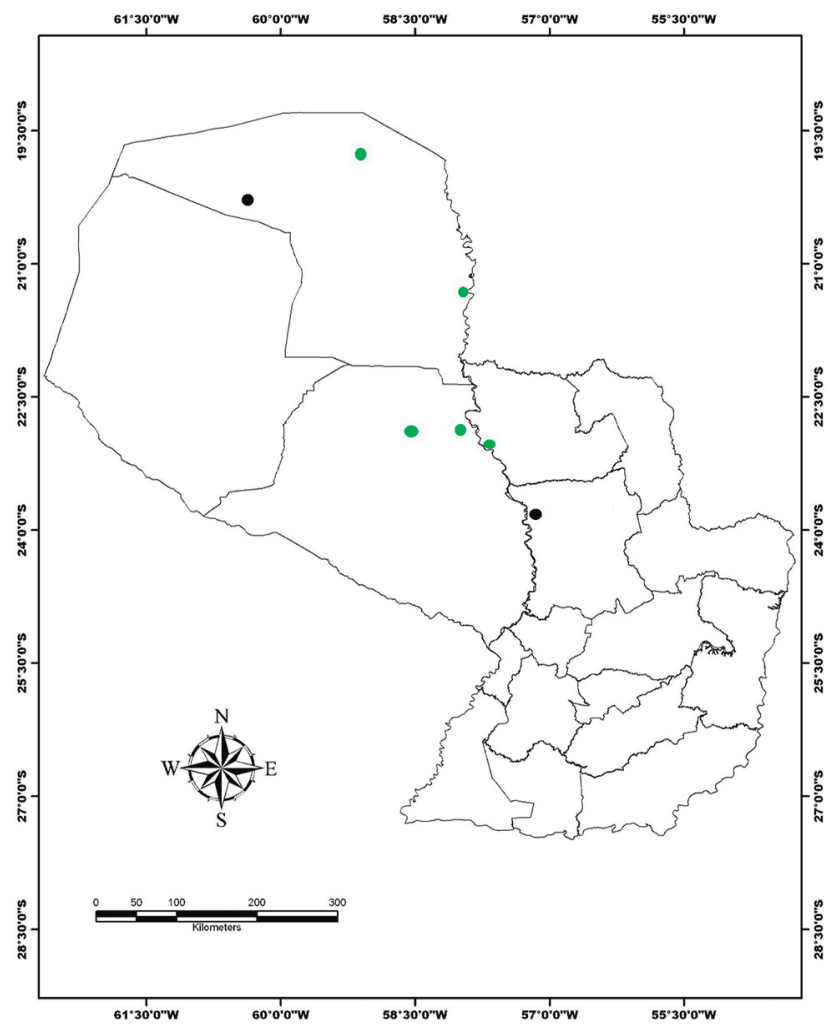

Figure 6. Distribution of Yellow-collared Macaw Primolius auricollis in Paraguay. Black dots: recent visual record, Green dots: specimen record.
Concepción department (Salvadori, 1895). The species is widespread and locally common in the Cerrado, Cerrados del Chaco and Pantanal ecoregions, but rare in the Humid Chaco ecoregion.

Published departmental records are as follows: Alto Paraguay (Orfila, 1936; Podtiaguin, 1944), Concepción (Salvadori, 1895; Podtiaguin, 1944; López, 1992) and Presidente Hayes (Laubmann, 1939; Podtiaguin, 1944).

Additional unpublished records of note are: Cerro León, Alto Paraguay department (PS, July 2006, sight record); Puerto Ybapobó, San Pedro department (Tatiana Galluppi, 14 March 2017, sight record), which extend the distribution slightly to the southwest in the Chaco and south in the Oriental region respectively.

Details of specimens that we are aware of are provided in Table 2.

\section{Blue-and-yellow Macaw Ara ararauna} Figs. 2, 7

The first Paraguayan mention was by SánchezLabrador (Castex, 1968) as Caninde, who described it as less often seen than $A$. chloropterus and an inhabitant of forests where they build their nests in the highest trees. Dobrizhoffer (1784) also mentioned it by the same name. Azara (1805) described it as his "No. 272 Guacamayo canindé", noting that the species did not pass $24.5^{\circ} \mathrm{S}$ and was not to be found within "50 leagues of Asunción" $(277.8 \mathrm{~km})$. It is worthy of note that the Paraguayan department Canindeyú derives its name from the local name for this species.

Since then, there have been very few published reports. Brabourne (1914) described the species as gathering in large numbers during March to feed on Yataity fruits at a point "c. 67 miles north of Villarrica" (approximating to modern day Yataity del Norte, San Pedro department), noting that a birdcatcher made a yearly visit to this point and had recently (at the time of writing) captured 50 individuals in a single trip. Bertoni (1922) already noted that the species was disappearing because of persecution and that the range was confined to the "north between Caaguasú and ... the Cordillera de Maracayú". These areas presumably correspond broadly to the localities listed in Bertoni (1939): Yhú, Caaguazú department (extending Azara's distributional limit south 
Table 2. Paraguayan specimens of Yellow-collared Macaw Primolius auricollis.

\begin{tabular}{|c|c|c|c|c|c|}
\hline Specimen & Locality & Department & Date & Collector & Source \\
\hline MACN & Puerto Guaraní & Alto Paraguay & 03 September 1928 & Daguerre & Orfila (1936) \\
\hline FMNH 15828, 15829, & Puerto Casado & Alto Paraguay & 08 June 1945 & Willim & Vert Net \\
\hline FMNH 15830 & Puerto Casado & Alto Paraguay & 11 June 1945 & Willim & Vert Net \\
\hline KU 90194 & Picada Chovoreca & Alto Paraguay & 22 September 1999 & Peterson & Vert Net \\
\hline NHM Published field numbers 242,252 & Colonia Risso & Concepción & $\mathrm{N} / \mathrm{A}$ & Salvadori & Salvadori (1895) \\
\hline ZSM 32.380 & Puerto Casado km 40 & Presidente Hayes & 31 July 1931 & Krieg & Laubmann (1939) \\
\hline
\end{tabular}

by over 0.5 degrees), Mbaracayú, Canindeyú department and "Chaco" without providing details. Three Paraguayan localities in Ñeembucú department given by Zotta (1937) under the name of Ara caninde presumably refer to this species, these being Villa Franca, Desmochados, and Guzu-Cua (= Guazu Cua), though the source of this information is a mystery. Podtiaguin (1944) repeats previously published localities and adds Colonia San Lázaro, Concepción department, as well as mentioning a now lost specimen from Pedro Juan Caballero, Amambay department shot by S. Vogt on 05 October 1933 and a which was formerly deposited in the Museo de Historia Natural del Paraguay.

As late as Inskipp et al. (1988) the statement that there are "no confirmed records" in Paraguay appeared in print, and a lack of subsequent records led Hayes (1995) to consider the species "extirpated in Paraguay". However there continued to be occasional undocumented reports by locals from Canindeyú (Mbaracayú Forest Reserve), Concepción (Paso Bravo and Serranía San Luís National Parks), Amambay (Bosque Estrella, Acevedo et al., 1990) and Alto Paraguay (northwest of Bahía Negra) depart-

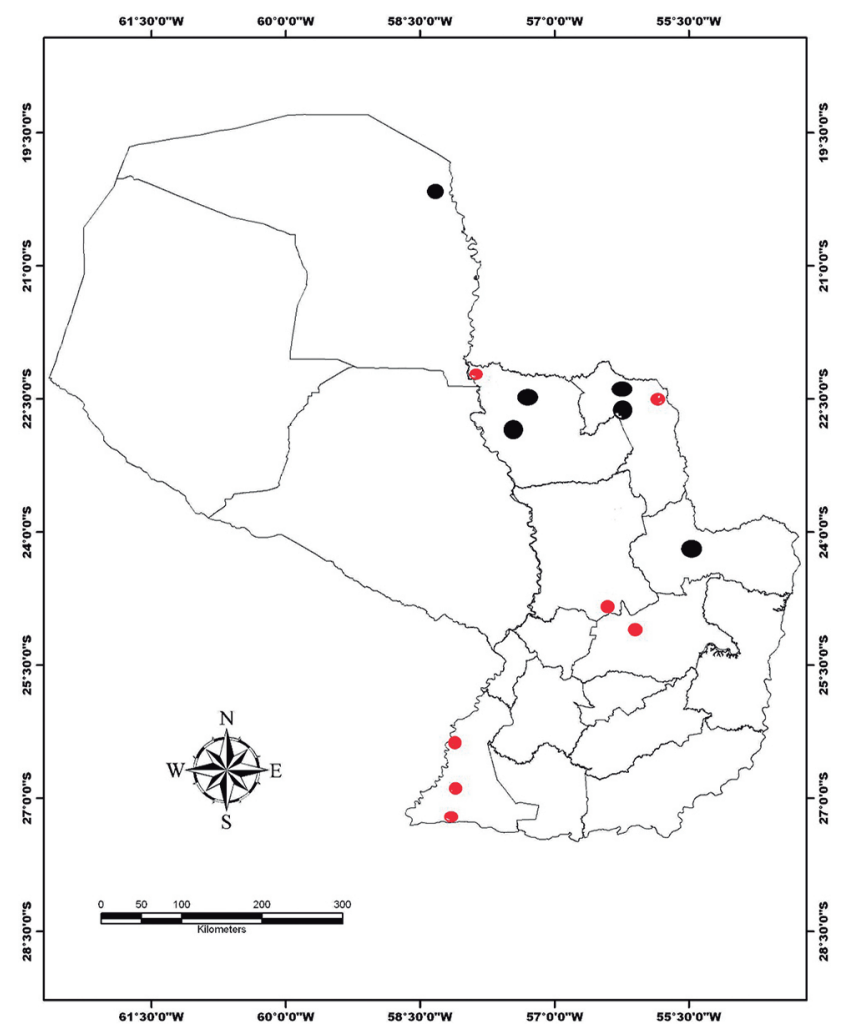

Figure 7. Distribution of Blue-and-yellow Macaw Ara ararauna in Paraguay. Black dots: recent visual record, Red dots: historical bibliographic record. ments (Mazar Barnett \& Madroño-Nieto, 2003; Guyra Paraguay, 2004).

More recently the species has been documented photographically at Estancia Cerro Corá, 12 km S of Bahía Negra, Alto Paraguay department (Gustavo Arévalos, 26 July 2013); on the Aquidabán River on the road north to Bella Vista del Norte (OR, 30 October 2010) (Fig. 3) and at Estancia Laguna Ciervo (OR, 26 April and 12 July 2017), both in Amambay department. It is suspected that some birds at the latter locality may roost in Brazilian territory and cross the border into Paraguay to feed.

We are unaware of any surviving Paraguayan specimens of this species.

\section{Red-and-green Macaw Ara chloropterus} Fig. 8

First reported by Sánchez-Labrador (Castex, 1968) as Guaa picta (Guaa pyta = "red macaw" in the Guaraní language), who described how the feathers of the species

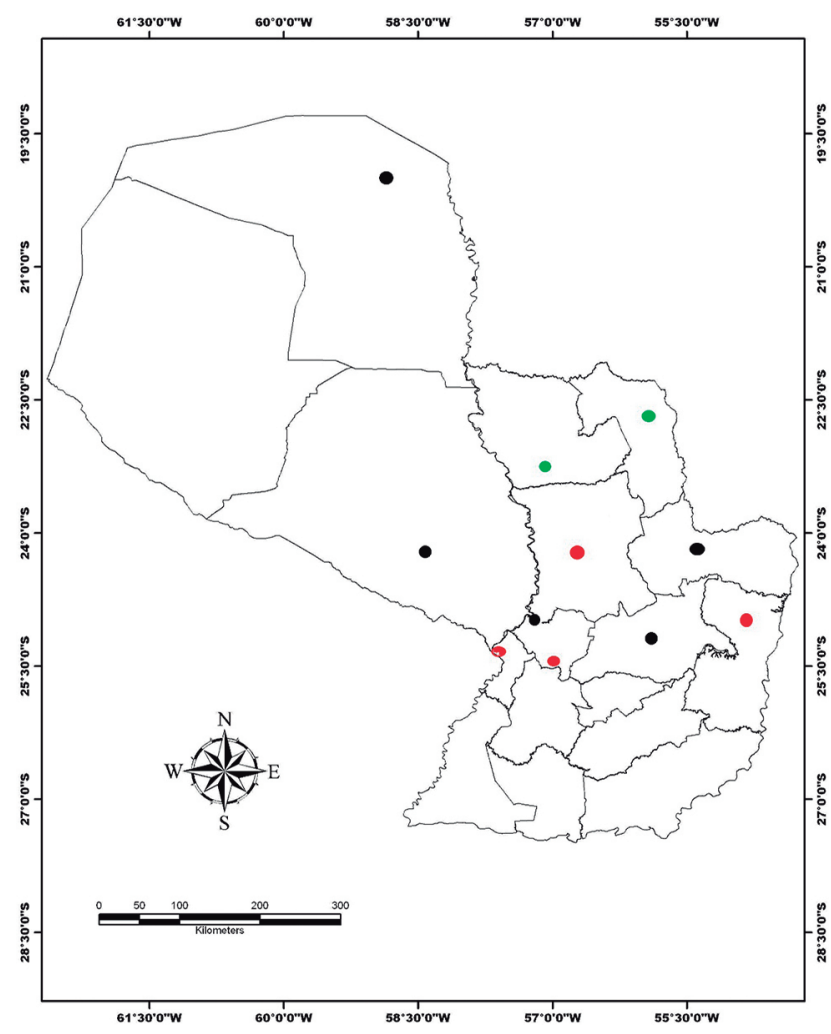

Figure 8. Distribution of Red-and-green Macaw Ara chloropterus in Paraguay. Black dots: recent visual record, Red dots: historical bibliographic record, Green dots: specimen record. 
Table 3. Paraguayan specimens of Red-and-green Macaw Ara chloropterus.

\begin{tabular}{|c|c|c|c|c|c|}
\hline Specimen & Locality & Department & Date & Collector & Source \\
\hline UMMZ 70464 & $45 \mathrm{~km}$ E of Paraguay River at the Tropic of Capricorn & Concepción & 17 February 1932 & Schulze & VertNet \\
\hline UMMZ 93292 & $5 \mathrm{~km}$ E Horqueta & Concepción & 23 February 1937 & Schulze & VertNet \\
\hline CUMV 9969 & Horqueta & Concepción & 10 September 1937 & Schulze & VertNet \\
\hline UMMZ 98101 & $2 \mathrm{~km}$ E Horqueta & Concepción & 10 September 1937 & Schulze & VertNet \\
\hline UMMZ 98103 & 2 km E Horqueta & Concepción & 03 November 1937 & Schulze & VertNet \\
\hline UMMZ 98102 & 2 km E Horqueta & Concepción & 04 December 1937 & Schulze & VertNet \\
\hline MACN X2 & "Paraguay" & N/A & $\mathrm{N} / \mathrm{A}$ & Boccard & Orfila (1936) \\
\hline MACN & "Paraguay" & N/A & N/A & Turner & Orfila (1936) \\
\hline USNM 352777 & "Paraguay" (Questionable?) & $\mathrm{N} / \mathrm{A}$ & $\mathrm{N} / \mathrm{A}$ & Page Expedition & $\mathrm{N} / \mathrm{A}$ \\
\hline
\end{tabular}

were used in indigenous ceremonies. He also makes reference to the fact that some people claim that the female is blue above and yellow below. Whilst he correctly clarifies that this description refers to the Blue-and-yellow Macaw A. ararauna, it is could be interpreted as a possibly very early reference to mixed species pairs between these species, a phenomenon that is well known today. Dobrizhoffer (1784) mentioned it by the name "quaá" or "quacomayo".

Azara (1805) described it as his "No. 273 Guacamayo roxo", adding that the species was "not abundant" and doubted whether it occurred south of $28^{\circ} \mathrm{S}$. He provides reproductive details and relates an anecdotal account of a hunter Manuel Palomares who killed an individual in April 1788 and had its partner follow him back to his house in central Asunción, Central department. This provides the earliest date and locality for the species. This is perhaps relevant because it indicates a historic presence of the species in Central department. The species still occurs in Asunción to this day, though there has been a recent tendency to assume these individuals are escapes (as at least some probably are).

The species is widespread but at low density in eastern Paraguay, and of marginal occurrence, but frequent west of the Paraguay River in the Cerrados del Chaco and Pantanal, and more rarely in Humid Chaco. Published records exist from Alto Paraguay (Podtiaguin, 1944; Hayes, 1995), Alto Paraná (Podtiaguin, 1944), Amambay (Podtiaguin, 1944), Caaguazú (Brabourne, 1914; Hayes, 1995; Lowen et al., 1996), Canindeyú (Podtiaguin, 1944; Hayes, 1995; Lowen et al., 1996; Mazar Barnett \& Madroño-Nieto, 2003), Central (Azara, 1805; Podtiaguin, 1944), Concepción (Laubmann, 1939; Podtiaguin, 1944; López, 1992; Hayes, 1995; Robbins et al., 1999), Cordillera (Rengger, 1835), Presidente Hayes (Bertoni, 1930; Podtiaguin, 1944; Hayes, 1995) and San Pedro departments (Smith et al., 2005, 2016). The Paraguayan locality (or localities) "Guacamayo, Alto Paraná" listed by Naumburg (1930) for this species cannot be traced, and may not be a locality at all given that guacamayo means macaw.

Additional unpublished records of note include a pair flying close to Puerto Naranjahai, Cordillera department (OR, 30 May 2015), confirming the continued presence of this species in this department, previously mentioned only by Rengger (1835) for near Piribebuy, and a pair crossing the Ruta Transchaco between km 120 and 130,
Presidente Hayes department (Francisco Fraccia \& Angel Brusquetti, 13 October 2009).

Details of specimens that we are aware of are provided in Table 3.

\section{Newly Documented Species}

\section{Red-shouldered Macaw Diopsittaca nobilis}

\section{Figs. 3, 9}

At approximately 06:00 on 01 May 2017 two individuals of this species were photographed by OR north of the headquarters of Estancia Laguna Ciervo (S 22 ${ }^{\circ} 17^{\prime} 43.64^{\prime \prime}$, W $\left.56^{\circ} 09^{\prime} 51.55^{\prime \prime}\right)$, Amambay department. The estancia is located some $40 \mathrm{~km}$ southeast of the town of Bella Vista Norte, and the northern and northeastern limits of the estancia are formed by the Brazilian border, delimited

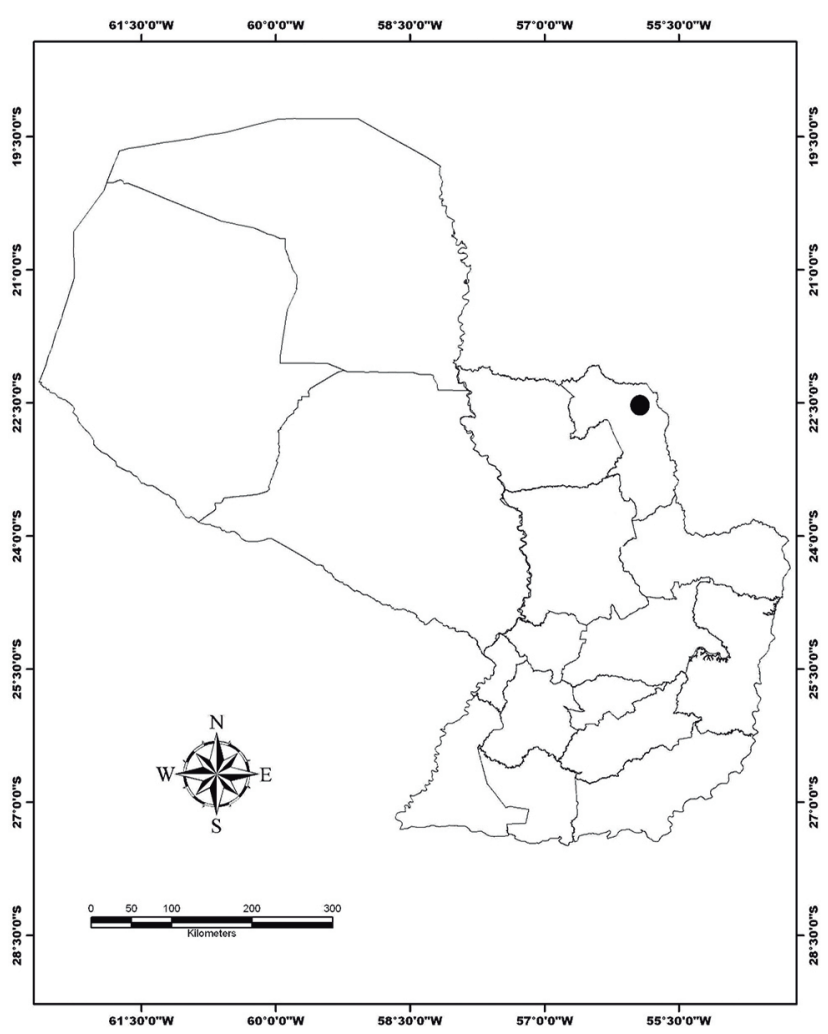

Figure 9. Distribution of Red-shouldered Macaw Diopsittaca nobilis in Paraguay. Black dots: recent visual record, Red dots: historical bibliographic record, Green dots: specimen record. 
by the Arroyo Estrella. The habitat is an area of transition between Cerrado and Atlantic Forest and the estancia is dedicated to cattle ranching. The same afternoon three individuals were encountered nearby at (S 22 ${ }^{\circ} 19^{\prime} 00.65^{\prime \prime}$, W $\left.056^{\circ} 11^{\prime} 13.16^{\prime \prime}\right)$ and were again photographed (Fig. 4) (and seen by LC). A video of vocalising birds was taken and is available online https://www.youtube.com/ watch? $\mathrm{v}=8-5$ LnedDRrw.

The individuals are tentatively referred to the subspecies Diopsittaca nobilis longipennis Neumann, 1931, which inhabits south-central Brazil (Collar, 1997). The closest previous reports to Paraguay that we are aware of are from Puerto Murtiño and west of Jardim, both in Mato Grosso do Sul state (data from eBird.org and Wikiaves.com.br). The Paraguayan records represent a range increase of $165 \mathrm{~km}$ southeast of these points.

Insufficient data is available to confirm the status of this species of Paraguay, but this area of the country has been largely neglected by fieldworkers. Confirming whether the presence of the species in Paraguay is seasonal, transitory or permanent will require further fieldwork. We note the close similarity of this species to Sánchez Labrador's Paracau mediano septima especie (Castex, 1968), perhaps an early overlooked reference to the species.

\section{Species of Possible Occurrence}

\section{Glaucous Macaw Anodorhynchus glaucus}

Widely considered to be globally extinct (Collar et al., 1992), Paraguayan records are all historical in nature and there is little clarity as to its previous distribution.

The species was first reported by Sánchez Labrador (Castex, 1968) who describes the Guaa obi (Guaa hovy = "blue macaw" in the Guaraní language) as abundant along the Uruguay River, but "rarely seen" along the Paraguay River. He makes specific reference to a captive bird owned by indigenous people at the town of "La Concepción de Nuestra Señora" but this locality was placed in Misiones, Argentina by Teixeira \& Papavero (2016). Sánchez Labrador (Castex, 1968) provides the only known report of the bird along the Paraguay River, but much of the northern course of this river is within the known range of Hyacinth Macaw. The Uruguay River however is within the known range of Glaucous Macaw and as Anodorhynchus macaws are considered to have allopatric distributions (Juniper \& Parr, 1998), it seems possible that the author may not have distinguished between the two species.

Azara (1805) described the species as his No. 273 Guacamayo azul, reporting the species along the Uruguay and Paraná Rivers between $27^{\circ}$ and $29^{\circ} \mathrm{S}$ "but never north of this". Considering the vagaries of latitude at this time, such a description could potentially be outside of the boundaries of modern day Paraguay. Berlepsch (1887) reflected this doubt, whilst Bertoni $(1914,1939)$ stated that Azara "hunted the species at the latitude of southern Paraguay, but along the Uruguay River", though this seems to infer additional information to that provided in Azara's (1805) text. Podtiaguin (1944) included "Rio Pelotas Kl. 3 (Alto Paraná)" in his distribution for the species, and this was associated with a stream south of Salto del Guairá, Canindeyú department by Collar et al. (1992) based on a $19^{\text {th }}$ Century map (Beyer, 1886). We have been unable to trace a copy of this map and can find no other reference to that name for any river in that area, consequently we consider it equally likely that the reference is to the Pelotas River which separates the Brazilian states of Rio Grande do Sul and Santa Catarina, and drains into the Uruguay River, this being more consistent with the documented range of the species.

Orfila (1936) mentions two specimens from "Paraguay" in the MACN, but other specimens with similarly vague data (NHM, ANSP, RMNH, MNRdJ) date from a time when the borders of Paraguay extended considerably further south than they do today (Finsch, 1867; Collar et al., 1992; Hayes, 1995; Teixeira \& Papavero, 2016) or are ex-zoo specimens (AMNH 474109, 474110) said to have originated in Paraguay. The species is retained as possible on the Paraguayan list because of the number of specimens purportedly from the country combined with the latitude provided by Azara just incorporating Paraguayan territory, but it is to be noted that concrete reports of the species from Paraguay are lacking.

\section{Rejected Species}

\section{Military Macaw Ara militaris}

Not evaluated by Guyra Paraguay (2004). A specimen in the Geneva museum (MHNG 133030) lacks collection data other than the entry date 1831 and includes a note "probably Paraguay" that expresses clear doubt about the provenance. This is clearly in error and the specimen must have originated elsewhere as the ecoregions in which the species occurs are not found in Paraguay.

\section{Blue-throated Macaw Ara glaucogularis}

Wagler's (1832) name Ara caninde was based on Azara's (1805) description of his Guacamayo caninde. This was for a long time thought to apply to the Bolivian endemic Blue-throated Macaw Ara glaucogularis. However, the identity was confirmed as this species by Bertoni (1922) and Dabbene (1920, 1921) with further clarification provided by Ingels et al. (1981). It seems that all Paraguayan reports can be traced back to this confusion. Two supposed Paraguayan specimens in the NHM mentioned by Forshaw (1973) are in fact from elsewhere (Ingels et al., 1981).

Podtiaguin (1944) writes of a pair of Ara glaucogularis being killed in Colonia Esperanza (probably Guairá department) on 18 June 1939 by E. Ávila (though earlier in the same publication he attributes the record to "E. Krenitsky"), with another taken by P. Willim at Colonia Nueva Italia, Central department. The location of Colonia Esperanza is uncertain, as there is also a locality with this 
name in Presidente Hayes department (S 23⒌ ${ }^{\prime} 04.36 "$, W $\left.58^{\circ} 45^{\prime} 42.58^{\prime \prime}\right)$. He describes the species as "travelling a lot" in certain years and it "not being rare to find it in Paraguay". However, this is completely at odds with all available evidence, and as Podtiaguin had a tendency to write secondhand accounts of birds in a firsthand manner (Smith, 2016), it is far from clear whether he ever examined the specimens he wrote about.

\section{ACKNOWLEDGEMENTS}

We are particularly grateful to Ing. Diego Heisecke of Empresa La Admirable S.A. for allowing us to work at Estancia Laguna Ciervo. PS and $\mathrm{HdC}$ receive support from the PRONII program of CONACYT. Ulf Drechsel and Sergio Ríos made helpful comments on an earlier draft. OR thanks CONACYT for co-financing the project "Turismo Ornitológico y científico en el Paraguay - Nuevos Paquetes de Ecoturismo para el incentivo de la Conservación y el monitoreo de biodiversidad del Paraguay" presented by Desarrollo Turístico Paraguayo SRL., and co-financed with resources from FOCEM/ MERCOSUR, which allowed the field work during which some of this data was collected to be performed. We are grateful to Arne Lesterhuis, Tatiana Galluppi and Silvia Centrón for sharing their observations. Thomas Trombone (AMNH) provided timely and efficient assistance with specimen queries, for which we are extremely grateful.

\section{REFERENCES}

Acevedo, C.; Fox, J.; Gauto, R.; Granizo, T.; Keel, S.; Pinazzo, J.; Spinzi, L.; Sosa, W. \& Vera, W. 1990. Áreas prioritarias para la conservación en la Región Oriental del Paraguay. Asunción, Centro de datos de la Conservación.

Azara, F. de. 1805. Apuntamientos para la historia natural de los páxaros del Paraguay y Río de la Plata. Madrid, Imprenta de la Viuda de Barra. v. 2.

Berlepsch, H. von. 1887. Appendix systematisches verzeichniss in der Republik Paraguay bisher beobachteten vogelarten. Journal für Ornithologie, 35: 113-134.

Bertoni, A. de W. 1914. Fauna Paraguaya. Catálogos sistemáticos de los vertebrados del Paraguay. Asunción, M. Brossa.

Bertoni, A. de W. 1922. Errores sobre el Canindé de Azara. Revista de la Sociedad Científica del Paraguay, 1(3): 39-40.

Bertoni, A. de W. 1930. Anexo; Aves observadas por el Dr. A. Barbero Paraje Santa Jacinta en el Confuso (Chaco); Especies que no figuran en la colección de Posner. Revista de la Sociedad Científica del Paraguay, 2(6): 257-258.

Bertoni, A. de W. 1939. Catálogos sistemáticos de los vertebrados del Paraguay. Revista de la Sociedad Científica del Paraguay, 4: 3-60.

Beyer, C. 1886. Mapa de la República del Paraguay, 1:1,000,000. Libreria Alemana, Buenos Aires. (not seen by authors).

Brabourne, L. 1914. Aviculture in Paraguay. Aviculture Magazine, 3(5): 185-191.

Brooks, T.M.; Barnes, R.B.; Butchart, S.H.M.; Clay, R.P.; Esquivel, E.Z.; Etcheverry, N.I.; Lowen, J.C. \& Vincent, J.P. 1993. Bird surveys and conservation in the Paraguayan Atlantic Forest. Cambridge, UK, BirdLife International. (BirdLife International Study Report No. 57).
Castex, M.N. (Ed.). 1968. Sánchez Labrador: peces y aves del Paraguay natural ilustrado, 1767. Buenos Aires Compañia General Fabril.

Collar, N. 1997. Family Psittacidae (Parrots). In: del Hoyo, J.; Elliott, A. \& Sargatal, J. (Eds.). Handbook of the birds of the world volume 4 sandgrouse to cuckoos. Barcelona, Lynx Edicions. p. 280-477.

Collar, N.J.; Gonzaga, L.P.; Krabbe, N.; Madroño Nieto, A.; Naranjo, L.G.; Parker III, T.A. \& Wege, D.C. 1992. Threatened birds of the Americas: The ICBP/ IUCN red data book. 3.ed. Washington, Smithsonian Institution.

Dabbene, R. 1920. El "Canindé" de Azara es el Ara ararauna (Lin.). El Hornero, 2:56.

Dabbene, R. 1921. Algunas palabras más sobre el cambio de nombre del Ara caninde auct. El Hornero, 2: 225.

Dobrizhoffer, M. 1784. Historia de Abiponibus equestri, bellicosaque Paraquariae Natione. Viennae, Typis Josephi Nob. de Kurzbeck.

Finsch, F.H.0. 1867. Die papageien. Leiden, Brill. v. 1.

Forshaw, J.F. 1973. Parrots of the world. Melbourne, Lansdowne Press.

Guyra Paraguay. 2004. Lista comentada de las aves de Paraguay/Annotated checklist of the birds of Paraguay. Asunción, Guyra Paraguay.

Hayes, F. 1995. Status, distribution and biogeography of the birds of Paraguay. Albany, American Birding Association. (Monographs in Field Ornithology 1).

Hayes, F.E.; Goodman, S.M. \& López, N.E. 1990. New or noteworthy bird records from the Matogrosense region of Paraguay. Bulletin of the British Ornithologists Club, 110: 94-103.

Ingels, J.; Parkes, K.C. \& Farrand Jr., J. 1981. The status of the macaw generally but incorrectly called Ara caninde (Wagler). Le Gerfaut, 71: 283-294.

Inskipp, T.; Broad, S. \& Luxmore, R. (Eds.). 1988. Significant trade in wildlife: A review of selected species in CITES Appendix II. Volume 3 birds. Cambridge, UK., IUCN.

Juniper, T. \& Parr, M. 1998. Parrots: A guide to the parrots of the world. Surrey, UK, Pica Press.

Laubmann, A. 1939. Die vögel von Paraguay. Stuttgart, Strecker und Schröder. v. 1.

López, N. 1989. Informe preliminar sobre la distribución, ecología y estado de psitacidos del Departamento de Concepción, Paraguay. In: Acevedo Gomez, C. (Ed.). Encuentro Paraguayo-Argentino de Ornitologia, $2^{\circ}$. Resumenes y Programa. Buenos Aires, Imprenta Graphis S.R.L. p. 49.

López, N.E. 1992. Observaciones sobre la distribución de Psitacidos en el departamento de Concepción, Paraguay. Boletín del Museo Nacional de Historia Natural del Paraguay, 11: 2-25.

Lowen, J.C.; Bartrina, L.; Clay, R.P. \& Tobias, J.A. 1996. Biological surveys and conservation priorities in eastern Paraguay. Cambridge, UK, CSB Conservation Publications.

Madroño-Nieto, A.; Clay, R.P.; Robbins, M.B.; Rice, N.H.; Faucett, R.C. \& Lowen, J.C. 1997. An avifaunal survey of the vanishing interior Atlantic forest of San Rafael National Park, Departments Itapúa/Caazapá, Paraguay. Cotinga, 7: 45-53.

Mazar Barnett, J. \& Madroño-Nieto, A. 2003. Aves de la Reserva Natural del Bosque Mbaracayú: Guía para la identificación de 200 especies. Asunción, Guyra Paraguay/Fundación Moisés Bertoni.

Munn, C.A.; Thomsen, J.B. \& Yamashita, C. 1987. Survey and status of the Hyacinth Macaw (Anodorhynchus hyacinthinus) in Brazil, Bolivia and Paraguay. Unpublished report. [not seen by authors]

Naumburg, E.M.B. 1930. The birds of Matto Grosso, Brazil. A report on the birds secured by the Roosevelt-Rondon Expedition. Bulletin of the American Museum of Natural History, 60: 1-432.

Neumann, 0. 1931. Neue Unterarten südamerikanischer Vogel. Mitteilungen aus dem Zoologischen Museum in Berlin, 17: 441-445.

Orfila, R.N. 1936. Los Psittaciformes Argentinos Parte 1. El Hornero, 6: 197-224. 
Podtiaguin, B. 1944. Catálogo sistemático de las aves del Paraguay. Aumentado por las contribuciones al conocimiento de la ornitología paraguaya. Revista de la Sociedad Científica del Paraguay, 6(3): 7-120.

Rengger, J.R. 1835. Reise nach Paraguay in den Jahren 1818 bis 1826. Aarau.

Ridgely, R.S. 1981. The current distribution and status of mainland Neotropical parrots. In: Pasquier, R.F. (Ed.). Conservation of new world Parrots. Washington DC, Smithsonian Press. p. 233-284.

Robbins, M.B.; Faucett, R.C. \& Rice, N.H. 1999. Avifauna of a Paraguayan cerrado locality: PN Serranía San Luis, Depto. Concepción. Wilson Bulletin, 111: 216-228.

Salvadori, T. 1895. Viaggio del dott. Alfredo Borelli nella Republica Argentina en el Paraguay. Uccelli raccolti nel Paraguay, nel Matto Grosso, nel Tucuman e nella Provincia di Salta. Bollettino dei Musei di Zoologia et Anatomia Comparata delle R. Università di Torino, 10(208): 1-24.

Smith, P. 2016. More comments and recommendations on Paraguayan "hypothetical"species: Rheapennata (Rheidae), Buteogallus aequinoctialis (Accipitridae), Columbina passerina (Columbidae), Caprimulgus hirundinaceus (Caprimulgidae) and Atlapetes citrinellus (Emberizidae). Boletín del Museo Nacional de Historia Natural del Paraguay, 20: 53-56.

Smith, P.; del Castillo, H. \& Guest, K. 2016. Birds of Reserva Natural Laguna Blanca, departamento San Pedro, Paraguay and the imminent threats to their conservation. Revista Biodiversidad Neotropical, 6: 55-67.
Smith, P.; del Castillo, H.; Batjes, H.; Montiel, M.; Wainwright, B. \& Wechsler, S. 2005. An avifaunal inventory of Laguna Blanca, Departamento San Pedro, northeastern Paraguay. FAUNA Paraguay Technical Publication, 2: $1-16$.

Tavares, E.S.; Baker, A.J.; Pereira, S.L. \& Miyaki, C.Y. 2006. Phylogenetic relationships and historical biogeography of Neotropical parrots (Psittaciformes: Psittacidae: Arini) inferred from mitochondrial and nuclear DNA sequences. Systematic Biology, 55: 454-470.

Teixeira, D.M. \& Papavero, N. 2016. Um breve histórico das araras do gênero Anodorhynchus Spix, 1824 (Aves, Psittaciformes). Arquivos de Zoologia, 47(1): 1-32

Velázquez, M.C.; Ramírez Pinto, F. \& Rodríguez Montiel, I. 2010. Flora \& fauna amenazada de la Reserva Natural Privada Tapytá. Fundación Moises Bertoni, Asunción, Paraguay.

Wagler, J.G. 1832. Monographia psittacorum. Abhandlungen der Mathematisch-Physikalischen Klasse der Königlich Bayerischen Akademie der Wissenschaften, 1: 469-750.

Zotta, A.R. 1937. Lista sistemática de las aves Argentinas. El Hornero, 6: 531-554. 
APPENDIX 1

Gazetteer of localities cited in the text.

\begin{tabular}{|c|c|c|}
\hline Localities & Department & Coordinates \\
\hline Bahía Negra & Alto Paraguay & $20^{\circ} 14^{\prime} \mathrm{S}, 58^{\circ} 10^{\prime} \mathrm{W}$ \\
\hline Base Aérea V Adrián Jara & Alto Paraguay & $19^{\circ} 34^{\prime} \mathrm{S}, 59^{\circ} 24^{\prime} \mathrm{W}$ \\
\hline Cerro Chovoreca & Alto Paraguay & $19^{\circ} 17^{\prime} \mathrm{S}, 59^{\circ} 04^{\prime} \mathrm{W}$ \\
\hline Cerro León & Alto Paraguay & $20^{\circ} 26^{\prime} \mathrm{S}, 60^{\circ} 19^{\prime} \mathrm{W}$ \\
\hline Estancia Karenina & Alto Paraguay & $19^{\circ} 20^{\prime} \mathrm{S}, 59^{\circ} 22^{\prime} \mathrm{W}$ \\
\hline Picada Chovoreca & Alto Paraguay & $19^{\circ} 35^{\prime} \mathrm{S}, 59^{\circ} 16^{\prime} \mathrm{W}$ \\
\hline Puerto Casado & Alto Paraguay & $22^{\circ} 20^{\prime} \mathrm{S}, 57^{\circ} 55^{\prime} \mathrm{W}$ \\
\hline Puerto Guaraní & Alto Paraguay & $21^{\circ} 17^{\prime} \mathrm{S}, 57^{\circ} 55^{\prime} \mathrm{W}$ \\
\hline Puerto María & Alto Paraguay & $21^{\circ} 37^{\prime} \mathrm{S}, 57^{\circ} 56^{\prime} \mathrm{W}$ \\
\hline Aquidabán River on the road N to Bella Vista del Norte & Amambay & $22^{\circ} 41^{\prime} \mathrm{S}, 52^{\circ} 18^{\prime} \mathrm{W}$ \\
\hline Capitán Bado, 40 km WSW & Amambay & $23^{\circ} 25^{\prime} \mathrm{S}, 56^{\circ} 00^{\prime} \mathrm{W}$ \\
\hline Cerro Corá National Park & Amambay & $22^{\circ} 39^{\prime} \mathrm{S}, 56^{\circ} 00^{\prime} \mathrm{W}$ \\
\hline Estancia Laguna Ciervo & Amambay & $22^{\circ} 17^{\prime} \mathrm{S}, 56^{\circ} 10^{\prime} \mathrm{W}$ \\
\hline Pedro Juan Caballero & Amambay & $22^{\circ} 33^{\prime} \mathrm{S}, 55^{\circ} 43^{\prime} \mathrm{W}$ \\
\hline Caaguazú & Caaguazú & $25^{\circ} 28^{\prime} \mathrm{S}, 56^{\circ} 00^{\prime} \mathrm{W}$ \\
\hline Yhú & Caaguazú & $25^{\circ} 03^{\prime} \mathrm{S}, 55^{\circ} 55^{\prime} \mathrm{W}$ \\
\hline Estancia Itabó Rivas & Canindeyú & $24^{\circ} 20^{\prime} \mathrm{S}, 54^{\circ} 35^{\prime} \mathrm{W}$ \\
\hline Mbaracayú Forest Reserve & Canindeyú & $24^{\circ} 07^{\prime} \mathrm{S}, 55^{\circ} 23^{\prime} \mathrm{W}$ \\
\hline Salto del Guairá & Canindeyú & $24^{\circ} 04^{\prime} S, 54^{\circ} 18^{\prime} \mathrm{W}$ \\
\hline Asunción & Central & $25^{\circ} 16^{\prime} \mathrm{S}, 57^{\circ} 40^{\prime} \mathrm{W}$ \\
\hline Colonia Risso & Concepción & $22^{\circ} 22^{\prime} \mathrm{S}, 57^{\circ} 48^{\prime} \mathrm{W}$ \\
\hline Colonia San Lázaro & Concepción & $22^{\circ} 06^{\prime} \mathrm{S}, 57^{\circ} 58^{\prime} \mathrm{W}$ \\
\hline Estancia Arrecife & Concepción & $22^{\circ} 15^{\prime} \mathrm{S}, 57^{\circ} 28^{\prime} \mathrm{W}$ \\
\hline Estancia Buena Vista & Concepción & $22^{\circ} 22^{\prime} \mathrm{S}, 57^{\circ} 51^{\prime} \mathrm{W}$ \\
\hline Estancia Centurión & Concepción & $22^{\circ} 16^{\prime} \mathrm{S}, 57^{\circ} 33^{\prime} \mathrm{W}$ \\
\hline Estancia Estrella & Concepción & $22^{\circ} 07^{\prime} \mathrm{S}, 57^{\circ} 41^{\prime} \mathrm{W}$ \\
\hline Estancia Garay Kue & Concepción & $22^{\circ} 43^{\prime} \mathrm{S}, 57^{\circ} 22^{\prime} \mathrm{W}$ \\
\hline Estancia Loma Pora & Concepción & $22^{\circ} 33^{\prime} S, 57^{\circ} 23^{\prime} \mathrm{W}$ \\
\hline Estancia Primavera & Concepción & $22^{\circ} 27^{\prime} \mathrm{S}, 57^{\circ} 35^{\prime} \mathrm{W}$ \\
\hline Estancia Mirabeaud (Paso Bravo, NP) & Concepción & $22^{\circ} 24^{\prime} \mathrm{S}, 57^{\circ} 20^{\prime} \mathrm{W}$ \\
\hline Estancia Retiro San Luís de la Sierra & Concepción & $22^{\circ} 24^{\prime} \mathrm{S}, 57^{\circ} 28^{\prime} \mathrm{W}$ \\
\hline Estancia Santa Sofía (Paso Bravo, NP) & Concepción & $22^{\circ} 19^{\prime} \mathrm{S}, 57^{\circ} 10^{\prime} \mathrm{W}$ \\
\hline Horqueta & Concepción & $23^{\circ} 21^{\prime} \mathrm{S}, 57^{\circ} 03^{\prime} \mathrm{W}$ \\
\hline Retiro Satí (Paso Bravo, NP) & Concepción & $22^{\circ} 25^{\prime} \mathrm{S}, 57^{\circ} 10^{\prime} \mathrm{W}$ \\
\hline Serranía San Luís National Park & Concepción & $22^{\circ} 37^{\prime} \mathrm{S}, 57^{\circ} 26^{\prime} \mathrm{W}$ \\
\hline Vallemí & Concepción & $22^{\circ} 09^{\prime} \mathrm{S}, 57^{\circ} 57^{\prime} \mathrm{W}$ \\
\hline Zanja Morotí & Concepción & $22^{\circ} 31^{\prime} \mathrm{S}, 57^{\circ} 13^{\prime} \mathrm{W}$ \\
\hline Piribebuy & Cordillera & $25^{\circ} 28^{\prime} \mathrm{S}, 57^{\circ} 02^{\prime} \mathrm{W}$ \\
\hline Puerto Naranjahai & Cordillera & $24^{\circ} 58^{\prime} \mathrm{S}, 57^{\circ} 13^{\prime} \mathrm{W}$ \\
\hline Villarrica & Guairá & $25^{\circ} 47^{\prime} \mathrm{S}, 56^{\circ} 27^{\prime} \mathrm{W}$ \\
\hline $3.5 \mathrm{~km}$ E of San Rafael & Itapúa & $26^{\circ} 40^{\prime} \mathrm{S}, 54^{\circ} 54^{\prime} \mathrm{W}$ \\
\hline Desmochados & Ñeembucú & $27^{\circ} 07^{\prime} \mathrm{S}, 58^{\circ} 06^{\prime} \mathrm{W}$ \\
\hline Guzu-Cua & Ñeembucú & $26^{\circ} 52^{\prime} \mathrm{S}, 57^{\circ} 59^{\prime} \mathrm{W}$ \\
\hline Villa Franca & Ñeembucú & $26^{\circ} 18^{\prime} \mathrm{S}, 58^{\circ} 08^{\prime} \mathrm{W}$ \\
\hline Ruta Transchaco between $\mathrm{km} 120$ and 130 & Presidente Hayes & $24^{\circ} 25^{\prime} \mathrm{S}, 58^{\circ} 02^{\prime} \mathrm{W}$ \\
\hline Estancia Alegria & San Pedro & $23^{\circ} 33^{\prime} \mathrm{S}, 56^{\circ} 26^{\prime} \mathrm{W}$ \\
\hline Estancia Don Luís & San Pedro & $23^{\circ} 35^{\prime} \mathrm{S}, 57^{\circ} 00^{\prime} \mathrm{W}$ \\
\hline Estancia Guyra Campana & San Pedro & $23^{\circ} 30^{\prime} \mathrm{S}, 56^{\circ} 23^{\prime} \mathrm{W}$ \\
\hline Estancia Rancho 75 & San Pedro & $23^{\circ} 38^{\prime} \mathrm{S}, 57^{\circ} 04^{\prime} \mathrm{W}$ \\
\hline Puerto Ybapobó & San Pedro & $23^{\circ} 42^{\prime} \mathrm{S}, 57^{\circ} 12^{\prime} \mathrm{W}$ \\
\hline Rancho Zastrow Saba & San Pedro & $23^{\circ} 34^{\prime} \mathrm{S}, 56^{\circ} 18^{\prime} \mathrm{W}$ \\
\hline Yataity del Norte & San Pedro & $24^{\circ} 50^{\prime} \mathrm{S}, 56^{\circ} 20^{\prime} \mathrm{W}$ \\
\hline
\end{tabular}

